\title{
Effect of Blossom Density and Crop Load on Growth, Fruit Quality, and Return Bloom in 'Honeycrisp' Apple
}

\author{
Charles G. Embree ${ }^{1,2}$ and Marina T.D. Myra \\ Agriculture and Agri-Food Canada, Atlantic Food \& Horticultural Research \\ Centre, 32 Main Street, Kentville, Nova Scotia, B4N 1J5, Canada
}

\author{
Douglas S. Nichols and A. Harrison Wright \\ Nova Scotia Fruit Growers Association, Atlantic Food \& Horticultural \\ Research Centre, 32 Main Street, Kentville, Nova Scotia, B4N 1J5, Canada
}

Additional index words. Malus $\times$ domestica Borkh., biennial-bearing, manual blossom and fruitlet thinning, canopy volume, crop load adjustment, trunk cross-sectional area

\begin{abstract}
From 2003 to 2006, the blossom level and crop load of 'Honeycrisp' apple (Malus $\times$ domestica Borkh.) trees on M.26 rootstocks were adjusted to improve fruit quality and return bloom. The treatments consisted of manually removing flower clusters to 50, 100, and 150 per tree, then at $\approx 50 \mathrm{~d}$ after full bloom, the crop load was adjusted to 3,6 , and 9 fruit $/ \mathrm{cm}^{2}$ trunk cross-sectional area (TCSA), respectively. All flower and crop load adjustment significantly increased TCSA and canopy volume compared with the control. Classic biennial bearing was observed on the untreated control trees and those thinned to 150 blossom clusters per tree and 9 fruit $/ \mathrm{cm}^{2}$ TCSA and was mitigated for trees with 50 and 100 blossom clusters followed by crop load adjustment to 3 and 6 fruit $/ \mathrm{cm}^{2}$ TCSA, respectively. Fruit color the "on" year was always lower on the control trees; no difference was found in the "off" year. The treatments increased fruit weight proportional to crop load except for the 2004 "off" year. This study illustrates that for trees with $\approx 1 \mathrm{~m}^{3}$ canopy volume, the combined effects of blossom and crop load adjustment to 100 blossom clusters/tree followed by fruitlet adjustment to 6 fruit $/ \mathrm{cm}^{2}$ TCSA and below will induce consistent annual production for 'Honeycrisp'.
\end{abstract}

'Honeycrisp' is a popular new apple cultivar in the premium fresh-fruit marketplace (Rosenberger et al., 2004). Because of the high returns for 'Honeycrisp' in the North American markets, Nova Scotia growers are interested in learning how to efficiently manage this cultivar in their region (Nichols and Wright, 2003). The cultivar is hardy and responds well to the more northerly climates (Luby and Bedford, 1990). Although developed in Minnesota and described as a good annual cropper requiring no flower thinning, 'Honeycrisp' has exhibited an extreme propensity for overcropping resulting in biennial bearing (Crassweller et al., 2005; Embree and Nichols, 2005; Robinson and Watkins, 2003).

Received for publication 24 May 2007. Accepted for publication 1 Aug. 2007.

We express our appreciation to Ken McRae and Sherry Fillmore at AAFC-AAC for their statistical support and to Joan Hebb and Jake Hartenhof for their technical assistance.

We also thank the generous funding and support from Apple Lane Farm Inc., the Nova Scotia Fruit Growers' Association, Scotian Gold Cooperative Ltd., AgraPoint International, the National Research Council Industrial Research Assistance Program, and the Nova Scotia Technology Development Program 2005-2006 Project \#DEV 25-027. ${ }^{1}$ Principle Research Scientist.

${ }^{2}$ To whom reprint requests should be addressed; e-mailembreec@agr.gc.ca.
Biennial bearing is the tendency of a cultivar to cycle between a full ("on") crop year and a minimal ("off") crop year resulting in inconsistent fruit quality and quantity (Monselise and Goldschmidt, 1982). Biennial bearing can be controlled to some extent by managing crop load in the "on" year, but results vary with cultivar (Schwallier et al., 2006; Singh, 1948). Research has shown that blossom thinning is more effective than fruitlet thinning alone to increase the potential for return bloom (Byers, 1997; Johnson, 1995; Preston, 1954; Singh, 1948; Tromp, 2000), stimulate tree growth, and increase fruit size (McArtney et al., 1996). For many cultivars, the optimal crop load is between 5 and 6 fruit $/ \mathrm{cm}^{-2}$ trunk cross-sectional area (TSCA) (Robinson and Watkins, 2003), but this varies with cultivar and depends on many factors, including spur habit and tree vigor (Singh, 1948).

Managing blossom density and crop load to control the strong biennial nature of this cultivar is one of the greatest challenges for 'Honeycrisp' producers. To meet this challenge, we evaluated the impact of adjusting blossom density and subsequent crop load on growth, fruit quality, and return bloom.

\section{Materials and Methods}

Experimental site and design. The plot was located in Morristown in the Annapolis
Valley of Nova Scotia, Canada $\left(45^{\circ} 03^{\prime} 00 \mathrm{~N}\right.$; $\left.64^{\circ} 46^{\prime} 00 \mathrm{~W}\right)$. The 'Honeycrisp' trees were planted in 1996 on 'M.26' rootstocks. Trees were planted $1.5 \mathrm{~m}$ within rows and $4.5 \mathrm{~m}$ between rows. The 16 trees were chosen based on bloom density throughout the tree in 2003. Soil type is described as the Morristown series as a very dark grayish brown loam; fine, subangular blocky structure; friable with some shale fragments and $\mathrm{pH} 4.9$ (Cann et al., 1965). The orchard floor was sod-covered with a $1.2-\mathrm{m}$ herbicide strip and no supplemental irrigation was used.

Tree growth. Canopy volume (CV) was calculated using a geometrical model that accounts for the specific contours in shape of each tree $(\mathrm{CV}=[(1 / 4) \pi a b h] /[m(x)+m(y)+1]$ (Wright et al., 2006b) in which $a$ is the width of the tree parallel to the row at $75 \%$ of the canopy height, $b$ is the width of the tree perpendicular to the row at $75 \%$ of the canopy height, $h$ is canopy height, $m$ accounts for the shape contour of the tree, $x$ is the width of the tree base parallel to the row, and $y$ is the width of the tree base perpendicular to the row. The TCSA of each tree was calculated from the circumference measured $30 \mathrm{~cm}$ above the graft union.

Blossom cluster density and crop load. Each year, in late May, all blossom clusters on each tree were counted. Blossom density was calculated by dividing the number of blossoms by the TCSA. Each tree was ranked according to blossom density at $80 \%$ bloom and then allocated to one of four replicate blocks based on blossom density. Using a randomized blocking system, treatments including an untreated control, 50,100 , or 150 blossom clusters/tree with $\approx 1 \mathrm{~m}^{3}$ of canopy volume were assigned to individual trees within each block so that each treatment contained four trees.

Blossom clusters were removed by hand to the previously mentioned treatment densities at $80 \%$ full bloom and distributed evenly over the whole tree. After natural fruitlet drop at $50 \mathrm{~d}$ after full bloom (DAFB), the remaining fruit were adjusted to the crop load treatments 3,6 , or 9 fruit $/ \mathrm{cm}^{2}$ TCSA on the trees with 50,100, and 150 blossom clusters/tree, respectively.

Fruit weight and quality. The fruit was harvested when the background color changed from green to yellow, which occurred $\approx 120$ DAFB. The fruit was stored at $2{ }^{\circ} \mathrm{C}$ for $20 \mathrm{~d}$, and then removed from storage and allowed to equilibrate to room temperature. The weight and percent total surface showing a red-orange blush was recorded.

Statistical analysis. The data were analyzed using the analysis of variance procedure of the statistical program Genstat 5 (Genstat 5 Committee, 1993). TCSA was used as a covariate to normalize the blossom cluster calculations.

Because a significant effect was found for some treatments during the trial, Tukey studentized range test on the means for each treatment was performed on the crop load and blossom cluster data, whereas Bonferroni multiple comparisons were performed on the 
apple weight data using an error rate of $\alpha=0.05$ to determine which treatments were significantly different (SAS Institute, 1996).

\section{Results and Discussion}

Tree growth. Linear regression analysis demonstrated a treatment effect on the TCSA change over time (Fig. 1). Eighty-four percent of variability in TCSA was accounted for by the 3 fruit $/ \mathrm{cm}^{2}$ TSCA, $63 \%$ by 9 fruit/ $\mathrm{cm}^{2}$ TSCA, $61 \%$ by 6 fruit $/ \mathrm{cm}^{2}$ TCSA, and $49 \%$ by the control. Only in 2006 was there a significant difference between the treatments for the TCSA $(P=0.022)$. Some studies in the past have had difficulty linking a decrease in TCSA with increased crop load because of the many variables associated with cropping and tree growth, including cultivar and rootstock, age of trees, environmental and climatic factors, pruning regime, and sampling years (Rogers and Booth, 1964; Webster and Brown, 1980). However, in a more controlled study of young trees, Maggs (1963) showed that blossom removal doubled the TCSA compared with nonthinned trees. Byers (2003) states that total blossom removal of spur 'Rome' trees increased shoot growth $52 \%$ and trunk circumference $47 \%$.

All thinning treatments promoted a significantly larger canopy volume in 2006 than the control trees $(P=0.02)$ (Fig. 2). In this 4-year study, canopy volume increased $56 \%, 69 \%$, and $70 \%$ for the control, 3 fruit/ $\mathrm{cm}^{2}$ TSCA, and both the 6 and 9 fruit $/ \mathrm{cm}^{2}$, respectively (Fig. 2).

The results indicate that repeat adjustment of flower and crop load below 150 blossoms/ tree and 9 fruit $/ \mathrm{cm}^{2}$ TCSA will increase tree vigor. Other studies have also shown that shoot growth is inversely affected by crop load (Avery, 1969, 1970; Maggs, 1963). However, Rogers and Booth (1964) found a significant negative correlation between crop load and the following year shoot growth, but not necessarily the current year shoot growth. In the current study, canopy volume was only measured at the beginning in 2003 and the end in 2006 and therefore we cannot draw any conclusions whether current year thinning or previous year thinning is the main stimulator of vegetative growth.

Crop load. In 2003 and 2005, the 'Honeycrisp' trees in this trial were in an "on" year and thus the crop load at harvest accurately reflected the thinning treatments of 3,6, and 9 fruit $/ \mathrm{cm}^{2}$ TCSA (Fig. 3). During the "off" years when there was sufficient fruit set, the crop load was also adjusted to these levels. A pattern of biennial cropping remediation can be seen by studying the response for each treatment between the "on" and "off" years (Fig. 3). The nonthinned untreated control trees displayed extreme biennialism with practically no fruit in the 2004 and 2006 "off" years, and even the trees thinned to 9 fruit $/ \mathrm{cm}^{2}$ TCSA showed the tendency to biennialism. At 6 and 3 fruit $/ \mathrm{cm}^{2}$ TCSA, a more consistent annual production was achieved.

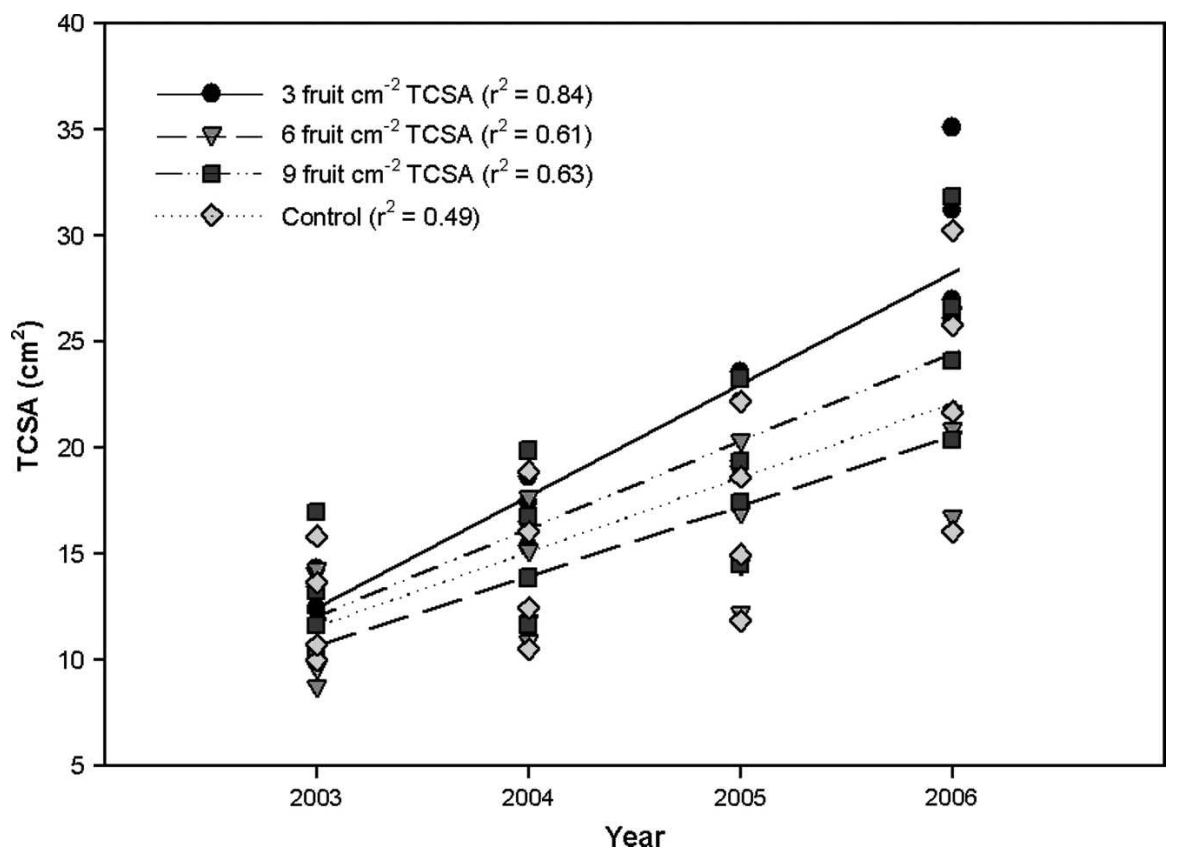

Fig. 1. Linear regression analysis of the trunk cross-sectional area (TCSA) over the 4-year trial for each experimental thinning treatment.

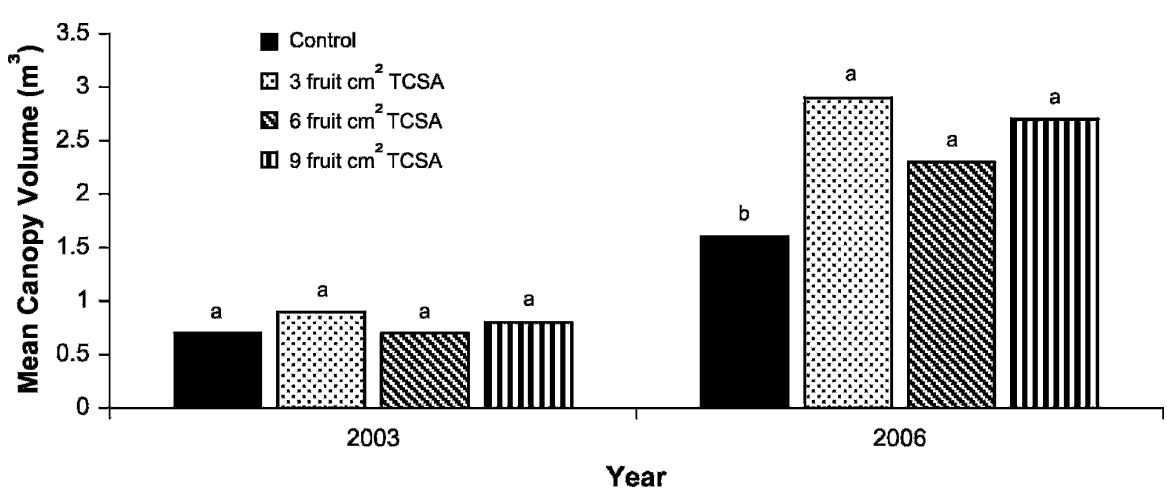

Fig. 2. Effect of flower and crop load adjustment on 'Honeycrisp' tree canopy volume for 2003 and 2006 $(P<0.05, \mathrm{n}=4)$.

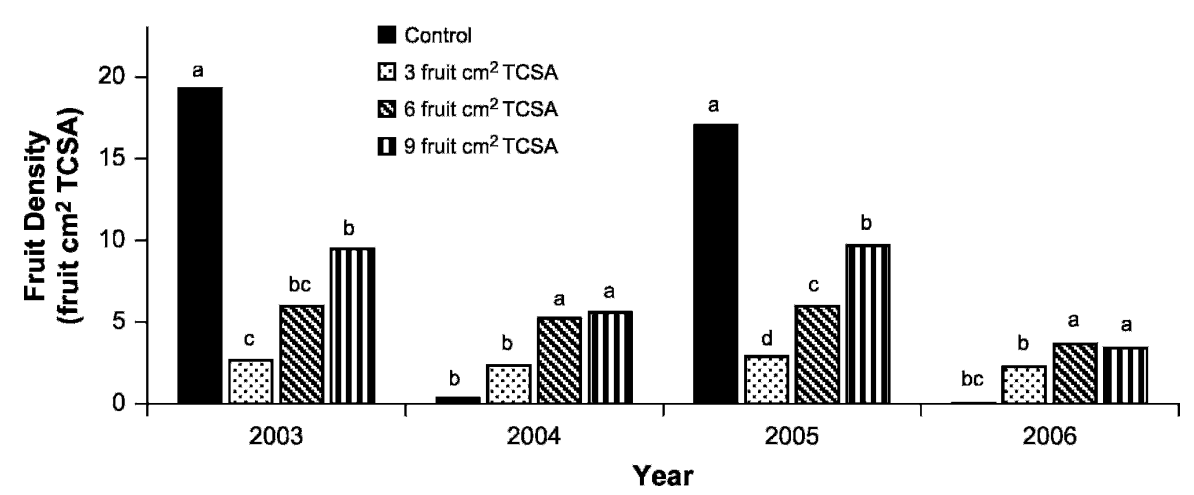

Fig. 3. Average 'Honeycrisp' crop load for each treatment from 2003 to 2006. Bars with different letters are statistically different within year by Tukey multiple comparison analysis $(P<0.05, \mathrm{n}=4)$.

Fruit quality. Fruit color was dramatically affected by the heavy cropping of fruit on the trees. During the 2004 and 2006 "off” years, there was no appreciable difference in fruit color (Table 1). During the 2003 and 2005 "on" years, a difference is seen between the treatments and especially in the control trees, which were overcropped and had greatly reduced coloration $(P<0.0001$ and $P=$ 0.002 , respectively). 
Similar to these results, Wright et al. (2006a) found that fruit color in 'Honeycrisp' was inversely proportional to crop load and yield when trees were manually adjusted (3, 6, and 9 fruit $/ \mathrm{cm}^{2}$ TCSA). 'Honeycrisp' can produce high-quality apples when crop load levels are optimum. Excessive crop loads have been reported to reduce color, fruit firmness, total acidity, soluble solids, and starch (Robinson and Watkins, 2003). Robinson and Watkins (2003) suggest that poor fruit color may be the result of less assimilate flow to each fruit. Their suggestion is also supported by the multiple site study in Wright et al. (2006a). These previous studies and the current findings support the use of chemical bioregulators to adjust current year crop loads for the production of high-quality 'Honeycrisp' apples (Embree and Nichols, 2005).

Treatments had a significant effect on the fruit weight in each of the 4 years of this study. In the 2004 "off" year, the magnitude of the difference between the crop loadadjusted trees and the control trees was less because of the low numbers of fruit on the control trees (Fig. 4). However, for the control trees, although the crop load was very low in the "off" years of 2004 and 2006, fruit were on average smaller than any of the three treatments that adjusted flowering and crop load.

The low fruit weight displayed by the control trees in this study and subsequent fruit weight increase in the thinned trees has been seen in previous 'Honeycrisp' studies (Embree and Nichols, 2005; Robinson and Watkins, 2003; Schupp, 2003; Wright et al., 2006a). Fruit size is determined by cell number, cell size, and intercellular space (Goffinet et al., 1995). However, cell number, which is determined early in apple development, accounts for most of the variation in fruit size (Pearson and Robertson, 1953), and it can be influenced by the previous year's crop load and may reduce the number of cells in the flower receptacles if it is excessive (Bergh, 1985). Therefore, the destined size of an apple may be determined by the current as well as previous year resources. Nonetheless, this study clearly shows the value of adequate crop load adjustment for increasing size in 'Honeycrisp'.

Return bloom. Return bloom was not significantly affected by treatments in the 2005 "on" year, but treatments did significantly affect the return bloom in the "off" years, 2004 and $2006(P<0.001$ and $P<0.01$,

Table 1. Average percent fruit color for all Honeycrisp apples on each tree for each thinning treatment for each year of the trial.

\begin{tabular}{|c|c|c|c|c|}
\hline \multirow[b]{2}{*}{ Treatment } & \multicolumn{4}{|c|}{ Yr } \\
\hline & 2003 & 2004 & 2005 & 2006 \\
\hline Control & 33 & 64 & 16 & 32 \\
\hline 3 fruit $/ \mathrm{cm}^{2}$ TCSA & 63 & 56 & 55 & 38 \\
\hline 6 fruit $/ \mathrm{cm}^{2}$ TCSA & 67 & 54 & 47 & 38 \\
\hline 9 fruit $/ \mathrm{cm}^{2}$ TCSA & 54 & 53 & 34 & 40 \\
\hline SEM & 3.01 & 4.49 & 5.22 & 7.42 \\
\hline F p & $<0.0001$ & 1.00 & 0.002 & 1.00 \\
\hline
\end{tabular}

TCSA $=$ trunk cross-sectional area. respectively) (Fig. 5). The propensity to increase the "on" years is almost double with a mean of $\approx 300$ blossoms/tree in 2004 and over 500/tree in 2006. The dramatic effect of cropping on biennial bearing is seen in the control trees in which return bloom is completely polarized (Fig. 5).

In the 2004 "off" year, trees in the control treatment had significantly fewer blossom clusters than those whose crop load had been adjusted to 3 and 6 fruit $/ \mathrm{cm}^{2}$ TCSA trees $(P<0.0001$ and $P=0.003)$ and also had more blossom clusters than the trees with 9 fruit $/ \mathrm{cm}^{2}$ TCSA.

In 2006, the 3 and 6 fruit $/ \mathrm{cm}^{-2}$ TCSA trees of 2005 displayed significantly more blossom clusters than the control trees $(P=0.008$ and $P=0.005$, respectively); however, none of the trees with adjusted flowers or fruit were significantly different nor were the trees with 9 fruit $/ \mathrm{cm}^{2}$ TSCA significantly different from the control.

These results show that reducing the crop to 6 fruit $/ \mathrm{cm}^{2}$ TCSA will significantly increase the number of blossom clusters above a nonthinned tree during the "off" years. The presence of fruit on the tree the previous season is known to be antagonistic to flower formation and is thought to be the result of hormones produced by the seeds (Chan and Cain, 1976). Many theories abound regarding the triggers of flower bud formation in pome fruits, and it is highly likely that a mixture of both physical and physiological factors contribute (Tromp, 2000). The results of this study and Wright et al. (2006a) suggest that both blossom and crop load reduction below certain levels alter the plant resource requirements sufficiently to increase fruit bud initiation the season after adjustment.

\section{Conclusion}

Blossom and fruitlet thinning are two of the most important tools apple growers can use in their attempts to affect biennial bearing fruit quality. Adequate flower and fruit thinning improves fruit characteristics such as color and size that are important to the fresh market. Results from the present study indicate that production of 'Honeycrisp' could be optimized for trees ranging in TCSA from 16 to $35 \mathrm{~cm}^{2}$ by adjusting blossom density to 100 blossom clusters/tree followed by a crop load adjustment to $\approx 6$ fruit $/ \mathrm{cm}^{2}$ TCSA. This supports a consistent crop load each year, barring any unforeseen environmental factors. Further research is warranted to more accurately quantify the individual and combined relationships between blossom and crop load on maximum yield and return bloom.

This study used hand-thinning to adjust blossom numbers and crop load, which is very time-consuming and costly. Commercially, blossom thinning using approved chemical applications would be more practical. There

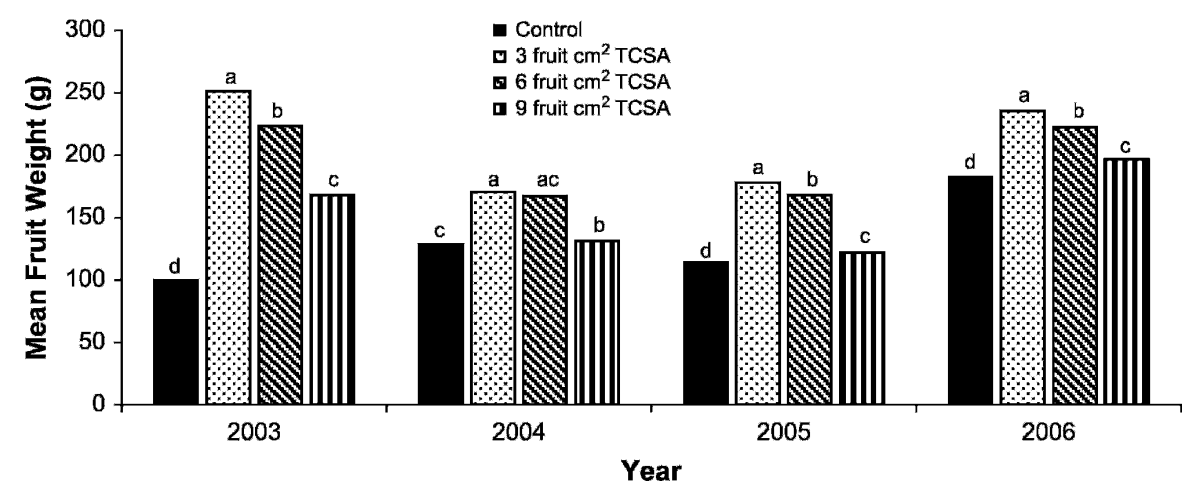

Fig. 4. Average 'Honeycrisp' fruit weight for each treatment from 2003 to 2006. Bars with different letters are statistically different within year by Bonferroni multiple comparison analysis $(P<0.05)$.

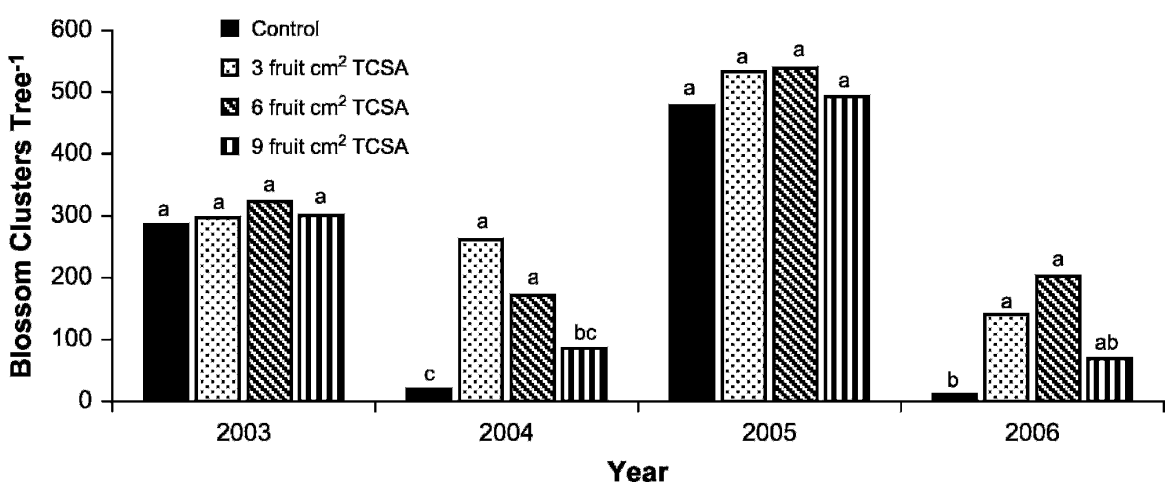

Fig. 5. Effect of adjusting flower and fruit levels on 'Honeycrisp' blossom clusters per tree before manual adjustments the year of treatment. Bars with different letters are statistically different within year by Tukey multiple comparison analysis $(P<0.05, \mathrm{n}=4)$. 
are a limited number of approved blossomthinning chemicals available to producers, and research into more environmentally friendly thinning agents is still in its early stages. More work is needed to determine optimal rates for existing products and to test new products to provide accurate blossom thinning.

\section{Literature Cited}

Avery, D.J. 1969. Comparisons of fruiting and deblossomed maiden apple trees, and nonfruiting trees on a dwarfing and an invigorating rootstock. New Phytol. 68:323-336.

Avery, D.J. 1970. Effects of fruiting on the growth of apple trees on four rootstock varieties. New Phytol. 69:19-30.

Bergh, O. 1985. Effect of the previous crop on cortical cell number of Malus domestica cv. 'Starking Delicious' apple flower primordia, flowers and fruit. South African J. Plant Soil 2:191-196.

Byers, R.E. 1997. Effects of bloom-thinning chemicals on apple fruit set. J. Tree Fruit Prod. 2:13-31.

Byers, R.E. 2003. Flower and fruit thinning and vegetative: Fruiting balance, p. 409-436. In: D.C. Ferree and I.J. Warrington (eds.). Apples: Botany, production and use. CABI Publishing, Wallingford, Oxon, UK.

Cann, B.D., J.I. MacDougall, and J.D. Hilchey. 1965. Soil Survey of Kings County, Nova Scotia. Report No. 15. Nova Scotia Soil Survey.

Chan, B.G. and J.C. Cain. 1976. The effect of seed formation on subsequent flowering in apple. Proc. Amer. Soc. Hort. Sci. 91:63-68.

Crassweller, R., R. McNew, A. Azarenko, B. Barrit, R. Belding, L. Berkett, S. Brown, J. Clemens, J. Cline, W. Cowgill, D. Ferree, E. Garcia, D. Greene, G. Greene, C. Hampson, I. Merwin, D. Miller, S. Miller, R. Moran, J. Obermiller, D. Rosenberger, T. Rom, T. Roper,
J. Schupp, and E. Stover. 2005. Performance of apple cultivars in the 1995 NE-183 regional project planting: I. Growth and yield characteristics. Journal for the American Pomological Society 59:18-27.

Embree, C.G. and D.S. Nichols. 2005. Bio-regulators improve fruit size and color and reduce crop load and annual bearing of Honeycrisp apples. Can. J. Plant Sci. 85:453-455.

Genstat 5 Committee. 1993. Genstat 5 Release 3. Clarendon Press, Oxford, UK.

Goffinet, M.C., T.L. Robinson, and A.N. Lasko. 1995. A comparison of 'Empire' apple fruit size and anatomy in unthinned and handthinned trees. J. Hort. Sci. 70:375-387.

Johnson, D.S. 1995. Effect of flower and fruit thinning on the maturity of 'Cox's Orange Pippin' apples at harvest. J. Hort. Sci. 70:541-548.

Luby, J. and D.S. Bedford. 1990. Honeycrisp apple. Regents of the University of Minnesota. U.S. Patent PP7,197. International Classification A01H 005/00.

Maggs, D.H. 1963. The reduction in growth of apple trees brought about by fruiting. J. Hort Sci. 38:119-128.

McArtney, S., J.W. Palmer, and H.M. Adams. 1996. Crop load studies with 'Royal Gala' and 'Braeburn' apples: Effect of time and level of hand thinning. N. Z. J. Crop Hort. Sci. 24:401-407.

Monselise, S.P. and E.E. Goldschmidt. 1982 Alternate bearing in fruit trees. Hort. Rev. (Amer. Soc. Hort. Sci.) 4:128-173.

Nichols, D. and H. Wright. 2003. How to grow 'Honeycrisp' apples for success. Nova Scotia Fruit Growers' Association: 140th Annual Report 2003. NSFGA, Kentville, N.S., Canada.

Pearson, J.A. and R.N. Robertson. 1953. The physiology of growth in apple fruits: IV. Seasonal variation in cell size, nitrogen metabolism, and respiration in developing Granny Smith apple fruits. Aust. J. Biol. Sci. $6: 1-20$.
Preston, A.P. 1954. Effects of fruit thinning by the leaf count method on yield, size and biennial bearing of the apple Duchess Favorite. J. Hort. Sci. 43:373-381.

Robinson, T.L. and C.B. Watkins. 2003. Cropload of 'Honeycrisp' affects not only fruit size but many quality attributes. New York Fruit Quarterly $3: 7-15$.

Rogers, W.S. and G.A. Booth. 1964. Relationship of crop and shoot growth in apple. J. Hort. Sci. 39:61-65.

Rosenberger, D.A., J.R. Schupp, S.A. Hoying, L. Cheng, and C.B. Watkins. 2004. Controlling bitter pit in 'Honeycrisp' apples. HortTechnology 14:342-349.

SAS Institute Inc. 1996. SAS Version 8.2. Cary, NC, SAS Institute Inc.

Schupp, J.R. 2003. Effects of chemical thinners on fruit set, yield, fruit size, and quality of 'Honeycrisp' apple. NewYork Fruit Quarterly 3:3-5.

Schwallier, P.G., P. Sabbatini, and M.J. Bukovac. 2006. Observations on the relationship between crop load and return bloom in 'Honeycrisp' apple. HortScience 41:1010 (abstr.).

Singh, L.B. 1948. Studies in biennial bearing II. A review of the literature. J. Hort. Sci. 24:45-65.

Tromp, J. 2000. Flower-bud formation in pome fruits as affected by fruit thinning. Plant Growth Regulat. 31:27-34.

Webster, D.H. and G.L. Brown. 1980. Trunk growth of apple tree as affected by crop load. Can. J. Plant Sci. 60:1383-1391.

Wright, A.H., C.G. Embree, D.S. Nichols, R.K. Prange, P.A. Harrison, and J.M. DeLong. 2006a. Fruit mass, colour and yield of 'Honeycrisp' apples are influenced by manuallyadjusted fruit population and tree form. J. Hort. Sci. Biotechnol. 81:397-401.

Wright, A.H., D.S. Nichols, and C.G. Embree. 2006b. Evaluating the accountability of trunk size and canopy volume models for determining apple production potential across diverse management regimes. Acta Hort. 707: 237-244. 